ISSN 2410-1176 (Print) Вісник КНУКіМ. Серія Мистецтвознавство. Вип. 39. ISSN 2616-4183 (Online)

methods of forming the structure of an on-screen spectacle. In vols. 5. vol. 3.]. Kyiv: Kyivskyi derzhavnyi instytut teatralnoho mystetstva.

3. Lissa, Z. (1970). Estetika kinomuzyki [Aesthetics of film music]. Moscow: Muzyka.

4. Mankovsky, V. (1984). Osnovy zvukooperatorskoi raboty [Fundamentals of sound producer's work]. Moscow: Iskusstvo.

5. Riazantsev, L. (2015). Tekhnika leitmotyviv v kinomuzytsi [The technique of leitmotifs in cinematic music]. Visnyk KNUKiM. Seriia: Mystetstvoznavstvo, issue 33. pp. 124-130.

6. Rozlogov, K. ed. (2005). Vvedenie v ekrannuyu kul'turu: novye audiovizual'nye tekhnologii [Introduction to screen culture: new audiovisual technology]. Moscow: Iskusstvo.

(C) Рязаниев Л. В., 2018

Стаття надійшла до редакиії: 05.02.2018

УДК 792.82.071.2.

Татаренко Марина Генадї̈вна

кандидат педагогічних наук, Київський національний університет

культури і мистеитв,

вул. С. Коновальия, 36, м. Київ, Україна, 01133, https://orcid.org/0000-0001-6838-3560 marina-lada-2012@ukr.net

Кожухова Надія Олександрівна магістр

Київький національний університет

культури і мистецтв,

вул. С. Коновальия, 36, м. Київ, Україна, 01133 , https://orcid.org/0000-0002-5141-4065

nadezhda.kozhuhova12@ukr.net

\title{
МЕТАФОРИКА КИЇВСЬКОГО ЕКСПЕРИМЕНТАЛЬНОГО ТЕАТРУ «ЗОЛОТІ ВОРОТА» ЯК ВІДЛУННЯ СВРОПЕЙСЬКОГО ТЕАТРАЛЬНОГО ПОСТМОДЕРНІЗМУ
}

Мета дослідження полягає у 3'ясуванні особливостей метафоричної режисури Київського експериментального театру «Золоті ворота» періоду 1984-2014 pp. Наукова новизна. Вперше аналізується феномен унікальної метафоричної лексики Київського експериментального театру «Золоті ворота» Методи дослідження. Історичний метод знадобився авторам для дослідження історії зародження метафорики «Золотих воріт», біографічний метод дозволив виявити коріння образної мови В. Пацунова, мистецтвознавчий метод сприяв аналізу художніх ознак метафорики «Золотих воріт». Висновки. Головною особливістю режисури Київського експериментального театру «Золоті ворота» періоду 19842014 pр. є поєднання системи «метафоричного» театру з системою театру «психологічного». Цей синтез грунтується на трьох «китах»: 1. Авторський метод генерування енергетичного поля вистави всіма іiі складовими: мистецтвом актора, режисера, сценографа та іншими співтворцями видовища. 2. Органічність метафоричної лексики режисера. 3. «Молекулярний» метод режисури. Усі ці ознаки обумовили практичну реалізацію В. Пацуновим концепції «Театру потрясіння» на сцені Київського театру «Золоті ворота». Дослідження унікальної сценічної лексики «Золотих воріт» періоду 1984-2014 рр. має велике значення для теорії та практики театрального мистецтва, для збагачення лексичного інструментарію сцени, для виховання нової генерації вітчизняної режисури. 
Ключові слова: метафорика театру; театр «Золоті ворота»; постмодернізм; «молекулярний метод» режисури; «Театр потрясіння».

Татаренко Марина Геннадиевна, кандидат педагогических наук, дочент, Киевский нацииональный университет культуры и искусств, ул. Е. Коновальца, 36, Киев, Украина

Кожухова Надежда Александровна, магистр Киевского национального университета культуры и искусств, ул. Е. Коновальца,36, Киев, Украина

Метафорика Киевского экспериментального театра «Золотые ворота» как отражение европейского театрального постмодернизма

Цель исследования. Показать особенности метафорической режиссуры Киевского экспериментального театра «Золотые ворота» периода 1984-2014 гг. Научная новизна. Впервые анализируется феномен уникальной метафорической лексики Киевского экспериментального театра «Золотые ворота». Методы исследования. Исторический метод понадобился авторам для исследования истории зарождения метафорики «Золотых ворот», биографический метод позволил выявить корни образного языка В. Пацунова, искусствоведческий метод способствовал анализу художественных признаков метафорики «Золотых ворот». Выводы. Главной особеностью режиссуры Киевского экспериментального театра «Золотые ворота» периода 1984-2014 гг. является сочетание системы метафорического театра с системой театра психологического. Этот синтез основывается на трех «китах»: 1. Авторский метод генерирования энергетического поля спектакля всеми ее составляющими: искусством актера, режиссера, сценографа и других соавторов зрелища. 2. Органичность метафорической лексики режиссера. 3. «Молекулярный» метод режиссуры. Все эти признаки обусловили практическую реализацию В. Пацуновым концепции «Театра потрясения» на сцене Киевского театра «Золотые ворота». Исследования уникальной сценической лексики «Золотых ворот» периода 1984-2014 гг. имеет большое значение для теории и практики театрального искусства, для обогащения лексического инструментария сцены, для воспитания нового поколения отечественной режиссуры.

Ключевые слова: метафорика театра; театр «Золотые ворота»; постмодернизм; «молекулярный метод» режиссуры; «Театр потрясения».

Tatarenko Maryna, PhD in Pedagogical Sciences, Kyiv National University of Culture and Arts, 36, Y. Konovaltsia St, Kyiv, Ukraine

Kozhukhova Nadiia, Master, Kyiv National University of Culture and Arts, 36, Y. Konovaltsia St, Kyiv, Ukraine

Metaphorics of the experimental theater "Kyiv Golden Gate Theater" as a reflection of European theaterical postmodernism

The purpose of the article is to define the peculiarities of metaphorical directing of the experimental theater "Kyiv Golden Gate Theater" during the period of 1984-2014. The scientific novelty of the work lies in the first attempt to analyze the unique metaphorical vocabulary of the experimental theater "Kyiv Golden Gate Theater". The research methodology. The historical method was used to study the history of the emergence of the metaphorics of the "Kyiv Golden Gate Theater"; the biographical method allowed for revealing the roots of V. Patsunov's figurative language; the art critical method contributed to the analysis of artistic features of the metaphorics of the "Kyiv Golden Gate Theater". Conclusions. The main characteristic feature of the metaphorics of the experimental theater "Kyiv Golden Gate Theater" during the period of 1984-2014 is the combination of the system of metaphorical theater with the system of psychological theater. This synthesis rests on three pillars: 1 . The author's method of generating the energy field of the play by all its components: the skill of the actor, director, scenographer and other composers of the spectacle. 2. Wholeness of director's metaphorical vocabulary. 3. The "molecular" method of directing. All these features conditioned the practical realization by V. Patsunov of the concept of "Theater of shock" on the stage of the "Kyiv Golden Gate Theater". Research into the unique scenic vocabulary of the "Kyiv Golden Gate Theater" during the period of 1984-2014 is of great 
importance to the theory and practice of theatrical art, the enrichment of lexical instrumentation of the stage and educating the new generation of domestic directing.

Key words: metaphorics of the theater; "Kyiv Golden Gate Theater"; postmodernism; "Molecular method" of directing; "Theater of shock".

Вступ. Українське театральне мистецтво, особливо його «провінційний» компонент (цим терміном автор позначає не стільки географічну приналежність театру, скільки «естетичну»), ще й досі не звільнився від побутово-етнографічного рудименту українського «театру корифеїв» кінця XIX ст., перетвореного Лесем Курбасом у 20-ті - 30-ті рр. XX ст. в європейську модель театру. Одначе, курбасівська європеїзація української сцени зустріла жорстокий супротив радянської системи та була винищена разом з іiі творцем. Соціальнополітичний та фізичний геноцид української народу здійснювався в купі 3 геноцидом духовним. Викорінювались паростки будь-якої свіжої думки, що не вписувалась у «прокрустово ложе» соціалістичного реалізму. Це відкинуло розвиток українського театру щонайменше на півстоліття. Наслідки цієї трагедії відчутні й донині - рідкісне явище української літератури чи театру перетинає державні кордони та органічно вписується у європейський елітний мистецький ландшафт. Тому заснування в 80-ті рр. XX ст. Київського театру Поезії, згодом перетвореного В. Пацуновим у Київський театр «Золоті ворота» як єдиний в Україні театр метафоричної естетики, стало непересічною подією на кшталт тектонічного вибуху, що утворив нове, образно-філософське русло театральної ріки на сценічній мапі України, ріки, що перетнула державні кордони та вийшла на європейський театральний простір. Дослідження успішного досвіду цього мистецького колективу сприятиме підвищенню рівня театральної освіти, слугуватиме ефективним подразником народження нової образної лексики вітчизняної сцени, що допоможе подолати побутовоетнографічний рудимент українського театру та підвищити його до кращих європейських зразків.

Аналіз останніх досліджень і публікацій. Існують сотні публікацій в засобах масової інформації про Київський театр «Золоті ворота», однак здебільшого вони мають не науковий, а компліментарний, рідше аналітичний характер. I лише кілька театрознавчих досліджень присвячено порушеній темі, серед яких варто згадати «Французькі театральні студії Владислава Корнієнка. Від тексту - до сцени» (Корнієнко, 2009), де автор аналізує метафорику «Золотих воріт»у виставах, здійснених за французькою драматургією. Так, розкриваючи метафоричну лексику вистав «Еврідика» Жана Ануя, «Калігула» Альбера Камю та «Собор Паризької Богоматері» за романом Віктора Гюго, В. Корнієнко обмежується лише іiі тлумаченням, залишаючи поза увагою як секрети режисерської лабораторії, так i художні ознаки унікальної образної мови. У театрознавчому дослідженні К. ЮдовоїРоманової «Технічні засоби оформлення сценічного простору» (Юдова-Романова, 2017) автор у відповідності з назвою видання обмежується лише описом метафоричної сценографії вистави «Бомж-ілюзіон» за п’єсою Христо Бойчева «Оркестр “Титаник”». От, власне, і все, що існує в науковій літературі 3 приводу унікальної метафорики «Золотих воріт», не враховуючи двох досліджень фундатора театру В. Пацунова (Пацунов, 2003, 2011), про що йтиметься далі. Отже, з цього короткого аналізу випливає, що метафорика «Золотих воріт», як яскрава ознака українського театру, досліджена недостатньо, тому потребує поглибленого вивчення.

Мета дослідження полягає у поглиблені уявлення про метафорику Київського експериментального театру «Золоті ворота» періоду 1984-2014 pp., у розкритті секретів режисерської лабораторії з перетворенняю літературної метафори в сценічну, у висвітленні алгоритму народження театрального образу, шляхів збільшення енергетичної потужності образної мови театру, а відтак, і сили впливу її на емоційну сферу глядача, що й обумовило практичне втілення В. Пацуновим розробленої ним концепції «Театру потрясіння».

Виклад основного матеріалу. Формування режисерського коду Валерія Пацунова відбувалось у напрочуд сприятливу для молодого режисера епоху, яку він назвав «Золотою Ерою режисури» (Пацунов, 2003). Адже європейська земля другої пол. ХХ ст. «вибухнула» сузір'ям реформаторів сцени світового рівня, яскравими, на наш погляд, представниками 
європейського театрального постмодернізму, серед яких були: Пітер Брук, Сжи Гротовський, Юрій Любимов, Петер Штайн, Еймунтас Някрошюс, Марк Захаров, Роман Віктюк... На цій могутній хвилі й народився Київський театр «Золоті ворота» як альтернатива засиллю побутово-етнографічного реалізму. Однак на ті ж часи припав і розквіт психологічного театру (Г. Товстоногов, А. Ефрос та О. Єфремов), під вплив творців якого також потрапив майбутній художній керівник «Золотих воріт». Синтез цих двох театральних напрямків метафоричного та психологічного - і склав режисерську платформу В. Пацунова.

Перша ж вистава в Театрі Поезії, згодом перейменованого у Київський театр «Золоті ворота», - «Кров та попіл» (1985) за поемою Юстінаса Марцинкявічуса стала гучним маніфестом нової образно-філософської театральної мови на українській сцені. «Метафора, за визначенням В. Пацунова, - $\epsilon$ перлиною мистецтва, вибухом пізнання, проникненням у суть явища, трансплантацією в Дух людини» 》 (Пацунов, 2003, с. 5). Красномовною перлиною тієї вистави став фінал сцени спалення фашистами жителів литовського села.

У Юстінаса Марцинкявічуса:

«О, Неман! Води пріснії свої ти в ненависть святую переплав.

Коли вони прийдуть до берегів, свій хрест та меч на берег поклади.

Як схиляться убивці на коліна, щоб заплямованії кров’ю руки

У річці омовить, здійметься хвиля, ненавистю збурена.

По лікоть спали їм руки ненавистю тою, -

Щоб не змогли вони тримати хрест - в лівій, в правій - меч».

У Валерія Пацунова: «В мертвій тиші, що настала після масового знищення селян, німецький офіцер, який керував стратою, вдивляється у перекошені судомою кисті своїх рук (певне, наслідок суворого окопного життя). Пальці тремтять від болю, і їм, звичайно, допоміг би холодний компрес. Офіцер повільно занурює палаючі кисті у колодязне відро з крижаною водою. I враз його обличчя спотворюється жахом - вода у відрі закипає! Вона буквально клекоче! Реальним клекотом! Реальним паром! Фашист миттю висмикує руки з окропу i, уражений тим, що сталося, задкує, не в змозі відірвати погляду від зіскаженілої води» (Пацунов, 2003, с. 83-84).

Так літературна метафора перетворилася на метафору театральну. Звернімо увагу на те, з якою «молекулярною» послідовністю режисер проробляє психологічний грунт, з якого має прорости органіка метафори: скрючені судомою кисті рук персонажа, відчуття болю, фізична потреба остудити руки в холодній воді, переляк від опіку рук окропом, відчуття жаху від метаморфози з водою тощо. Саме психологізм метафоричної лексики стає однією 3 визначальних ознак образної мови В. Пацунова, що забезпечує генерацію потужного енергетичного поля його видовищ. Прослідкуймо цю та інші ознаки на інших метафорах зазначеної вистави.

Одним з центральних сценографічних образів стало підвішене догори коромисло, що уособлювало терези: в обставинах фашистської окупації трагічний герой Мартінас мав зробити вибір - або зрадити своєму народові, або залишитись йому вірним, але з ризиком для життя. 3 обох дужок-терезів коромисла звисали додолу довжелезні шлейфи з тканини, обгорілої до стану попелу. Ті шлейфи в нервових руках Мартінаса натягували дужки-терези коромисла залежно від обставин, що над ним тяжіли, і коромисло своєю метушнею відтворювало емоції героя. Коли жага до безтурботного життя в союзі з фашистами в Мартінасі перемагала, то він «вагітнів» величезною купою попелу, яку жадібно здирав 3 коромисла та ховав за пазуху. Але коли він побачив спалене до попелу рідне село, а в тому попелі - труп вагітної дружини, то збагнув, що винуватцем цієї трагедії $є$ саме він. I ототожнивши себе з Каїном, Мартінас приймає рішення покарати себе самогубством. Режисер вдається до концентрованої метафори: під час монологу-покаяння герой поеми, вхопившись за обгорілу тканину, що простягнулась високо вгору до однієї з двох дужок коромисла, несамовито тягне іiі до себе, неначе намагаючись здійнятись до неба, як раптом тканина відривається від дужки терезів і коромисло, різко вирвавшись на волю, заходилось 
ISSN 2410-1176 (Print) Вісник КНУКіМ. Серія Мистецтвознавство. Вип. 39. ISSN 2616-4183 (Online)

гойдатись, немов ноги повішеного. Експресивний звукопис загострює сприйняття вражаючого режисерського прийому.

Як бачимо, в наведених епізодах художня логіка та послідовність поведінки персонажа, психологізм як актора, так і образного реквізиту надає метафорі необхідної органіки, а виставі - переконливої художньої правди.

Цією виставою режисер не лише оголосив маніфест театральної метафорики на українській сцені другої пол. XX ст., але й на противагу системі театру «переживання» презентував нову театральну ідею - концепцію «Театру потрясіння». На думку Пацунова, потрясіння в театрі можна досягти шляхом створення єдиного енергетичного поля, генерованого випроміненням акторів, сценографії, музики, шумів, режисури, об'єднаних режисером-постановником в єдиний могутній променевий пучок. Як відомо, феноменом випромінення актора вперше зацікавився ще на поч. ХX ст. К. Станіславський (Станіславський, 1954), однак про теоретичну розробку цього явища та впровадження його класиком режисури у театральну практику історикам театру невідомо. Пацунов присвятив все своє творче життя вивченню, розробці та практичній реалізації вищезгаданої ідеї Станіславського. Механізми процесу випромінення фундатор «Золотих воріт» розкриває в грунтовній праці «Станіславський у ХХ ст.: Культ? Міф? Чи реальність?»:

«За умов абсолютної зосередженості актора на внутрішніх процесах у момент гри в його організмі автоматично спрацьовує механізм «підзарядки», від чого енергетичні поля актора збуджуються і народжується акт випромінення енергії. Цей процес проживання я називаю «молекулярним». Саме на «молекулярному» рівні організм актора перетворюється на генератор променів, за допомогою яких і транспортується у публіку весь спектр устремлінь та відчуттів актора-ролі. Саме за цим опроміненням, не усвідомлюючи того, люди йдуть у театр. Їх цікавить не «що?», а «як?». Згадаймо, друзі, як в дитинстві ми за допомогою лінзи концентрували розсіяне сонячне світло в один гострий світловий пучок, яким випалювали візерунки на дереві, видобуваючи вогонь концентрованою енергією Сонця. За аналогічним фізичним законом видобувається «вогонь» актора. Його енергія, народжена гамою устремлінь та почуттів персонажа, зконцентрована в гострий пучок, генерує випромінення, що запалює душі та серця десятків, сотень, тисяч охочих до солодкого вогнища пристрастей театроманів, любителів спалахувати та згорати в солодкій пожежі пристрастей та емоцій» (Пацунов, 2011, с. 196).

Свою концепцію «Театру потрясіння» Пацунов успішно втілював у наступних виставах, серед яких варто виокремити «маленьку трагедію» О. Пушкіна «Моцарт і Сальєрі» (1986). Ось як виглядає у викладі режисера фінал цього унікального видовища, що перетнув межі пушкінського твору, здійнявши його на нечувану височінь:

«Чорно-білий ритм широких мармурових сходів графічно відтворює ритм клавіатури, символізуючи Сходи-Рояль. Танцюючи на Сходах-Роялі, “гуляка праздный” Моцарт на очах у трудоголіка Сальєрі “лівою ногою” буде викрешувати ноти безсмертного Requie. Осліплений генієм, Сальєрі не зможе творити. На самоті він буде молити Моцарта піти зі шляху, а дозрівши до вбивчого рішення, - здирати з “болвана” (пристосування у формі черепа для зберігання та виготовлення перук) моцартівську французьку перуку, немовби скальпуючи його голову.

Коли отруєний Моцарт назавжди відійде по клавіатурі Роялю вгору, перед Сальєрі, нарешті, відкриється шлях до клавіатури. Він люто накинеться на неї, намагаючись повторити генія, однак замість музики - німота! Він буде оскаженіло вбивати ноги в клавіші, але марно! Жодної ноти! I раптом Сальєрі уражає усвідомлення повної творчої імпотенції. Розум полишає вбивцю. Безцільно плентучись по підлозі, Сальєрі наражається на "скальповану" голову Моцарта, поднімає iї, ніжно притискає до щоки та, юродиво хихикаючи, хрипить у небеса: "Ужель он прав, и я не гений? Гений и злодейство - две вещи несовместные? Неправда! А Бонаротти? Иль это сказка тупой бессмысленной толпы - и не был убийцею создатель Ватикана?”» (Пацунов, 2003, с. 85-86). 
На цьому літературний текст Пушкіна закінчується, а метафоричний текст Пацунова продовжується:

«Раптом з мертвої тиші, немов з неба, вибухнула Lacrimosa Моцарта. Вона притискує Сальєрі до землі. Він шанобливо знімає капелюха перед магічними звуками геніального витвору. Та його починає душити божевільний сміх. Регочучи, він повзе до Сходів-Роялю. Наростає хор Lacrimosa, дужчає дикий регіт. Сальєрі дереться по клавіатурі догори, все вище й вище, туди, куди пішов Моцарт. I з кожним кроком чорні клавіші Роялю «плавляться», немов годинники Сальвадора Далі, утворюючи чорні хвости, що тягнуться услід Сальєрі. Лунає crescendo реготу безумця на fortissimo Lacrimosa Моцарта. Сальері зникає за обрієм. Залишилися сміх, Lacrimosa i нескінченне чорне багатохвостя, що повільно повзе, звільняючи білий мармур клавіатури від чорного лиходійства» (Пацунов, 2003, с. 86).

Цим вражаючим пластичним фіналом режисер «дописав» Пушкіна, створивши відсутній у поета акт покарання антигероя, та головне - вивів його на катарсис, що $є$ невід'ємною ознакою високої трагедії (згадаймо «Річард ІІІ» В. Шекспіра). Таким чином, жанровий статус «маленької трагедії» Пацунов здійняв до класичної трагедії. I цим домігся ефекту потрясіння. А головним інструментом режисера, як завжди, була перлина мистецтва метафора. Трансплантована в драматургічне тіло поета, вона своєю винятковою органічністю зобов'язана глибокому психологізму психофізичної партитури персонажа, художній логіці та послідовності його поведінки.

I, нарешті, сценічним шедевром, у якому режисер досяг найвищого рівня втілення концепції «Театру потрясіння», і який можна вважати візитною карткою «Золотих воріт» часів Пацунова, стала вистава «Убивець» на тему роману Ф. Достоєвського «Злочин і покарання» (1991). Головним сценографічним контрапунктом сценічного твору була труноподібна шухляда, з якої виростатиме лялька-лихварка. Оточений юрбою злиднів та навіжених з піднесеними над головами сокирами, Раскольніков боязко підкрадатиметься до ляльки та, подолавши зрештою страх, під багатоголосе “Хррряясь!” зриватиме голову з іiі плечей. Проте залишиться багряна артерія між головою та тулубом ляльки. Убивця спробує видерти і її, та марно - вона, немов реквізит фокусника, буде ще довго тягтися з тіла старої.

Відчувши небезпеку, Раскольніков спробує втекти, не випускаючи з рук голови жертви. Однак багряна артерія виявиться нескінченною. Метушлива спроба позбутися іiі заплутає Раскольнікова і багряне павутиння врешті-решт сплете все його тіло. Нарешті, зачепившись в утробі старої, артерія натягнеться, немов леска риболова. Цікавість охопить убивцю. Обережно перебираючи руками леску, він повільно підкрадатиметься до торса старої i, як завзятий рибалка, смикне леску. Однак вона не піддасться. Раскольніков щосили рвоне уперту леску і з черева небіжчиці вилетить... крихітний гаманець, що знущально погойдуватиметься на кінчику багряної артерії. Як бачимо, режисер створив багатозначну красномовну метафору і про тваринну скнарість лихварки, яка ховаває гроші у власному череві, і про знецінення людського життя, вартість якого тотожна крихітному гаманцю, і про багряне павутиння, яке обплутає злочинця.

«Убивець» протримався в репертуарі тридцять років, був тріумфатором багатьох міжнародних фестивалів. На найпрестижнішому у світі Единбурзькому (Шотландія) Міжнародному театральному фестивалі вистава отримала найвищий рейтинг - 5 зірок та була визнана європейькою пресою еталоном театрального мистецтва. За «Золотими воротами» закріпилась репутація одного 3 кращих камерних театрів світу. Завдяки унікальній метафоричній естетиці театр не лише міцно вписався у європейський елітний театральний простір, але й став його взірцем, майстер-класом для європейської режисури.

Не претендуючи на повне розкриття унікальності «Золотих воріт», автори лише здійснили першу спробу дослідження метафорики творчого колективу, який, втіливши концепцію «Театру потрясіння», додав до історії українського театру кілька золотих літер.

Наукова новизна дослідження полягає в тому, що вперше у мистецтвознавчій літературі аналізується феномен унікальної образної лексики єдиного в Україні театру метафоричної естетики - Київського експериментального театру «Золоті ворота» періоду 
ISSN 2410-1176 (Print) Вісник КНУКіМ. Серія Мистецтвознавство. Вип. 39. ISSN 2616-4183 (Online)

1984-2014 рр. та пов'язаної з ним концепції «Театру потрясіння», розробленої та впровадженої у сценічну практику фундатором театру Валерієм Пацуновим. Ця концепція має всі ознаки новаторства, як і театр «Золоті ворота», аналогів якому на театральній мапі Європи не існує, що неодноразово відзначала як вітчизняна, так і європейська преса.

Висновки. Головною характерною ознакою метафорики Київського експериментального театру «Золоті ворота» періоду 1984-2014 рр. є поєднання системи метафоричного театру з системою театру психологічного. Цей синтез грунтується на:

- авторському методі генерування енергетичного поля вистави всіма ії складовими: мистецтвом актора, режисера, сценографа та іншими співтворцями видовища;

- на органічності метафоричної лексики;

- на «молекулярному» методі режисури.

Усі ці ознаки забезпечили реалізацію В. Пацуновим розробленої та впровадженої ним концепції «Театру потрясіння» на сцені Київського театру «Золоті ворота», та й поза їі межами.

Метафорична лексика не належить певному часові чи певній епосі, це позачасова філософсько-поетична мова мистецтва, тому метафорика «Золотих воріт», сплітаючи 3 вічних проблем людського духу образне мереживо сцени, є актуальною на всі часи, на кшталт сценічним витворам Пітера Брука, Юрія Любимова, Еймунтаса Някрьошюса та інших поетів сцени останньої чверті XX ст. Саме тому дослідження унікальної лексичної спадщини Київського експериментального театру «Золоті ворота» періоду 1984-2014 рр. потребує продовження, позаяк має вагоме історичне, пізнавальне та виховне значення для розвитку вітчизняної театрознавчої науки та театральної освіти.

\section{Список використаних джерел}

1. Корнієнко В. В. Франиузькі театральні студї Владислава Корнієнка. Від текстудо сцени. Київ : Знання України, 2009. 224 с.

2. Пацунов В. П. Театральна вертикаль. Київ : КНУКіМ, 2003. 120 с.

3. Пацунов В. П. Станиславский в XXI в.: Культ? Миф? Или реальность? Киев : Макрос, 2011. 214 с.

4. Станиславский К. С. Собрание починений. В 8 т. Т. 2. Москва : Искусство, 1954. 424 с.

5. Юдова-Романова К. В. Технічні засоби оформлення сценічного простору. Київ : КНУКіМ, 2017. 316 с.

\section{References}

1. Korniienko, V. (2009). Frantsuzki teatralni studii Vladyslava Korniienka. Vid tekstu - do stseny [Vladyslav Korniienko's French theatrical studios. From the text to the scene]. Kyiv: Znannia Ukrainy.

2. Patsunov, V. (2003). Teatralna vertykal [Theatrical vertical]. Kyiv: Kyiv National University of Culture and Arts.

3. Patsunov, V. (2011). Stanislavsky v XXI veke.: Kul't? Mif? Ili real'nost'? [Stanislavsky in the twenty-first century: Cult? Myth? Or reality?]. Kyiv: Makros.

4. Stanislavsky, K. (1954). Sobranie sochinenii. B 8 t. T. 2. [Collection of works. In 8 vol. Vol. 2.]. Moscow: Iskusstvo.

5. Yudova-Romanova, K. (2017). Tekhnichni zasoby oformlennia stsenichnoho prostoru [The technical means of designing the stage space]. Kyiv: Kyiv National University of Culture and Arts.

(C) ТатаренкоМ. Г., 2018

(C) Кожухова H. A., 2018

Стаття надійшла до редакиії: 31.06 .2018 